\title{
The state of environmental performance evaluation in the public sector: the case of the Portuguese defence sector
}

\author{
Tomás B. Ramos ${ }^{\mathrm{a}, *}$, Inês Alves ${ }^{\mathrm{b}}$, Rui Subtil ${ }^{\mathrm{b}}$, João Joanaz de Melo ${ }^{\mathrm{a}}$

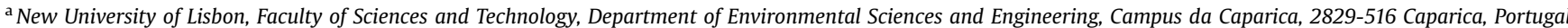 \\ ${ }^{\mathrm{b}}$ University of the Algarve, Faculty of Marine and Environmental Sciences, Campus de Gambelas, 8000-117 Faro, Portugal
}

\section{A R T I C L E I N F O}

Article history:

Received 28 March 2007

Received in revised form 31 January 2008

Accepted 28 February 2008

Available online 15 April 2008

\section{Keywords:}

Defence sector

Environmental performance evaluation

Indicators

Questionnaire survey

\begin{abstract}
A B S T R A C T
The environmental performance evaluation (EPE) of organizations is becoming an autonomous management tool. The main goal of this research was to assess the state of EPE practice in the Portuguese defence sector, as a particular part of public services. A questionnaire survey was conducted involving all Portuguese military units that have a person in charge of environmental issues. The questionnaire was designed to assess: (i) the importance and drivers of EPE; (ii) the ISO 14031 knowledge and implementation; (iii) the knowledge and use of environmental indicators; (iv) the optimal format for indicators; and (v) the advantages and drawbacks of using environmental indicators. Despite various initiatives driving environmental practices in public organizations, most of that experience is only centred on an environmental management system, and EPE is quite a new issue. Nevertheless, general environmental performance evaluation is a growing reality and one in which Portuguese military units are taking an increasing interest. Overall respondents agree on the importance of measuring and communicating environmental performance related to their main missions and activities. The main drivers for EPE in military units are the prevention of health risks and compliance with regulations. However, to date, ISO 14031 and environmental performance indicators are almost unknown in the respondent military units. Among the three military branches, the Navy revealed the worst environmental performance evaluation knowledge, awareness and practice.
\end{abstract}

\section{Introduction}

The expression environmental performance is often used in different contexts with distinct objectives, meanings and broad domains. Accordingly, it may reflect different issues such as: (i) the trend in environmental improvement, (ii) the state of the environment, (iii) the environmental efficiency, and (iv) the compliance of one or more environmental aspects with the regulations, and several others. Despite the different meanings, a number of environmental management and policy tools use the expression environmental performance: environmental auditing, environmental impact assessment, environmental risk assessment and environmental management systems (EMS), among others.

Recently, with the publication of the international standard ISO 14031:1999, by the International Organisation for Standardization (ISO), the concept of environmental performance evaluation (EPE) has been accepted as an autonomous environmental management tool. This standard integrates the 14,000 families of voluntary

\footnotetext{
* Corresponding author. Tel.: +351 21 2948397; fax: +351 212948554 .

E-mail address: tabr@fct.unl.pt (T.B. Ramos).
}

international environmental standards and it is not for certification or registration purposes. According to this standard EPE is: "a process to facilitate management decision regarding an organization's environmental performance by selecting indicators, collecting and analysing data, assessing information against environmental performance criteria, reporting and communicating, and periodically reviewing and improving this process" [1]. At organization level several authors (e.g. Refs. [2-5]) tried to define the scope and boundaries of the concept, however, this is a hard task. As stressed by Wathey and O'Reilly [2] the concept tends to differ from publication to publication. For example, the definition given in ISO 14031 differs from that given in ISO 14001:2001 (International Standard for EMS).

In this paper a broader EPE definition is assumed, as a tool, targeting not only organizations but also entire economic sectors. Environmental performance is understood here as part of performance management and assessment overall, as defined by Armstrong and Baron [6]. A broad definition of environmental performance indicators is similarly assumed.

EPE can be applied to all kinds of organizations and sectors (private or public), regardless of type, dimension, complexity, country or place of location. Major private organizations now are 
beginning to evaluate and report their environmental and social performances as they do with their financial performance. Stakeholder pressure, efficiency and competitiveness, marketing and public image, legal requirements and international commitments are factors that can explain this trend. In the public sector, though the evolution is slower, EPE is also becoming a growing reality.

At a public sector level there are numerous initiatives involving the implementation of environmental management practices, e.g. EMS, environmental audits and EPE, including measurement and communication. However, most of this experience is centred on the adoption of EMS, as stated by Ramos et al. [7]. In the public sector, environmental performance assessment itself is quite a new issue, despite a certain amount of experience in overall performance management and assessment (e.g. Refs. [8-11]), usually related to accounting. Nevertheless, some work analyses the environmental measurement and communication aspect in particular (e.g. Refs. [12-17]). Some countries are implementing broader initiatives (e.g. the United Kingdom, Canada) through sustainable programs of greening government.

The measuring of management success is now required by the United States (US) Government Performance and Results Act of 1993 (GPRA) (US Government [18]), whereby agencies must develop program performance reports based on goals and indicators. The United States Department of Energy and the United States Environmental Protection Agency (USDOE/USEPA) [15] underline that GPRA does not require agencies to include environmental measures. Nevertheless, if an agency chooses to do so, performance indicators used to meet EMS' goals and targets can be combined on an agency-wide basis and included in an agency's GPRA measures. The US uses a whole variety of particular performance frameworks that should be taken into account when comparing with other realities, such as the European. In the US different standards apply.

Despite certain examples related to EPE approaches (e.g. Refs. [19-22]) and environmental indicators (e.g. Refs. [23-27]) most of the environmental experience in the public sector (including defence) is related to EMS (e.g. Refs. [28-39]).

The adoption of EPE practices by Portuguese organizations, both private and public, is only done on a voluntary basis, without any mandatory regulation or standard. There are various initiatives involving corporate EPE, including measurement, communication and reporting. Some Portuguese firms already publish their environmental and sustainability reports, both paper and Internet versions. Regarding the particular area of environmental accounting, Portugal has adopted the European Commission Recommendation of 30 May 2001 (2001/453/EC) on the Recognition, Measurement and Disclosure of Environmental Issues in the Annual Accounts and Annual Reports of Companies. It proposes the publication of a regulation on national environmental accounts by the Portuguese accounting standards authority. Accordingly, the Directriz Contabilística no 29 - Matérias Ambientais of the Comissão de Normalização Contabílistica came into force for accounts closed after January 1, 2006.

The main goal of the present research was to assess the practice of EPE in the Portuguese defence sector. To accomplish this goal, a questionnaire survey was conducted among military units. This study includes the bases, garrisons, agencies and commands of the Portuguese armed forces; for the sake of simplicity, the expression military unit was adopted to represent all military organizations encompassed by the study. The questionnaire was designed to assess the knowledge, use and drivers of EPE and indicators. It was developed by the university research team and conducted under the authority of the Portuguese Ministry of Defence (MDN).

Previous research included an assessment of the environmental profile, through the evaluation of how environmental management practices have been adopted in the sector and an assessment of environmental aspects and impacts $[7,40]$.

\section{Methodology}

The Portuguese defence sector under the MDN is one of the largest public services, with a large number of civilian employees, military personnel and reservists. Like other public services, the defence sector oversees many facilities and operations, including the use of large areas of land.

The total expenditure of the Portuguese defence sector represents about $1.2 \%$ of GDP and $3.2 \%$ of public sector expense. In 2001 manpower stood at 42,677 (including 3382 reservists), down from 62,300 in 1990 [41]. In 1995 the MDN assumed its first environmental commitments under the national environmental policy [42]. This policy was recently updated [43] and came into force in its revised form with the publication in 2002 of the Portuguese version of the North Atlantic Treaty Organization (NATO) Standardization Agreement [44]. This states the environmental doctrine for NATO-led operations and exercises and provides guidance in environmental planning for all military activities. However, these two documents do not give any specific guidelines for EPE adoption and implementation. The environmental policy of the Portuguese Armed Forces includes a general recommendation that the Armed Forces Command must support the dissemination of environmental information. Additionally, several other environmental initiatives are being taken by the MDN and military branches, showing a rising interest in achieving a better performance, but without any specific military regulation for EPE.

The MDN environmental policy was designed to be adopted by the three military branches at the different levels of the organization, resulting in one environmental policy plan per each branch. This policy is focused on peacetime missions and activities. The Air Force was the first military branch that adopted an environmental policy, approved in 1997. The national policy defines three main organizational levels to coordinate and implement this strategy: (i) the military Commander-in-Chief - coordination and planning; (ii) the national agencies/departments and territorial commands control of the implementation and programming; and (iii) the military units - implementation. To put into practice the policy, environmental offices and military environmental managers are being created or adapted from existing procedures related to quality and security. At the end of this process, all military units should have an environmental office or environmental manager, in charge of integrating environmental aspects in their defence mission, preferably through an EMS.

This research analyzes part 2 of a questionnaire (see Appendix) mailed in October 2003 to 74 military units (part 1 results were reported by Ramos et al. [7]). Questionnaires were mailed from the Portuguese Minister of Defence to all the Portuguese military units having a known person in charge of environmental issues; this was considered as the population of the study. Those units represent approximately $25 \%$ of the total number of Portuguese military units, $35 \%$ of all Portuguese military personnel and $55 \%$ of the total land area used by the defence services. Fifty-three out of the 74 military units returned usable responses to the questionnaire, a response rate of $72 \%$. The respondents included the three military branches: the Air Force - 13 units; Army - 17 units; and Navy - 23 units.

According to the adopted definition of military unit, one facility or camp may include several independent units that fulfil the criterion of having a person in charge of environmental issues.

The second part of the questionnaire focuses on the state of EPE in the military, covering the following issues:

(a) the importance of EPE;

(b) drivers of EPE;

(c) ISO 14031 knowledge and implementation;

(d) knowledge and use of environmental indicators; 
(e) the optimal format for indicators; and

(f) the advantages and drawbacks/limitations of using environmental indicators.

Descriptive statistics were used to analyse the results. Chisquare was computed to test associations between frequency distributions among the military branches [45].

In order to combine the results obtained by each question, an index - the State of environmental performance evaluation (SEPE) was developed to process the information in a simplified and useful manner. The SEPE index gives an aggregated picture of the knowledge, awareness and practice of EPE in the units. Five variables from the group of questions (a), (c) and (d) were used in the index. A normalization procedure was used to transform the raw data into a continuous scale of variation $[0, \ldots, 1]$, allowing the aggregation processes. 0 Is the worst value, 1 is the best. The SEPE index was computed using the following equation:

$\mathrm{SEPE}=\sum_{j=1}^{m} \frac{\left[\sum_{i=1}^{n} \frac{X_{i}}{n}\right]_{j}}{m}$

where $X_{i}=$ the environmental performance of the variable $i$; $n=$ total number of $i$ variables, $i=1, \ldots, 5$; and $m=$ total number of $j$ military units, $j=1, \ldots, 74$.

Five categories were defined to classify the state of the EPE, which the index provided in a range from 0 to 1 : very poor: $0-0.20$; poor: 0.21-0.40; medium: 0.41-0.60; good: 0.61-0.80; and excellent: $0.81-1$. This index is not designed to assess any individual military unit, i.e., this evaluation does not rank the respondent units. The SEPE approach was conducted for each military branch and for the entire Portuguese military sector. Spearman's correlation non-parametric test was performed to assess the relationship between unit size (land area and personnel) and the SEPE index. To investigate potential differences among the SEPE index groups a non-parametric test, the Kruskal-Wallis test $[45,46]$, a one-way analysis of variance using ranks, was performed. The test was applied to the following groups: (i) military branch: Army, Air Force and Navy; and (ii) geographical location by NUTS II region (according to the European Common Classification of Territorial Units for Statistics - NUTS): Alentejo, Algarve, Centro, Lisboa e Vale do Tejo, Norte, Açores and Madeira.

It should be said here that comparisons between the Portuguese military and others should be viewed with caution, because there are major underlying differences, including size of the defence sector and military units, and institutional, political, cultural, economic and military development aspects.

\section{Results and discussion}

\subsection{EPE background}

\subsubsection{The importance of EPE}

About $75 \%$ of the units agree on the importance of evaluating environmental performance, including measuring and communicating performance related to their main missions and activities (Table 1 ). The results by branch show a similar pattern for the Air Force and Army. The Navy presents a more balanced pattern, with $39 \%$ of respondents stating that this practice is not important. This result could be justified by a poor environmental profile of the Navy units, with few environmental management practices implemented, including EMS adoption, based on ISO 14001 standard, as shown in previous research [40]. Many factors could explain this behaviour, such as fair environmental training and the commanders' and managers' environmental unawareness. The
Table 1

Importance of environmental performance evaluation for the respondents' units ( $\mathrm{f}=$ frequency)

\begin{tabular}{|c|c|c|c|c|c|c|c|c|c|}
\hline \multirow[t]{2}{*}{ Question } & \multirow[t]{2}{*}{ Category label } & \multicolumn{2}{|c|}{ Air force } & \multicolumn{2}{|c|}{ Army } & \multicolumn{2}{|c|}{ Navy } & \multicolumn{2}{|c|}{ Total } \\
\hline & & $f$ & $\%$ & $f$ & $\%$ & $f$ & $\%$ & $f$ & $\%$ \\
\hline \multirow[t]{6}{*}{ Importance of EPE } & Yes & 10 & 84 & 16 & 94 & 13 & 57 & 39 & 75 \\
\hline & No & 1 & 8 & 1 & 6 & 9 & 39 & 11 & 21 \\
\hline & Don't know & 1 & 8 & 0 & 0 & 1 & 4 & 2 & 4 \\
\hline & Nonresponses & 1 & & 0 & & 0 & & 1 & \\
\hline & Total & 12 & 100 & 17 & 100 & 23 & 100 & 52 & 100 \\
\hline & Chi-square test & \multicolumn{8}{|c|}{ Significant for $p<0.05$} \\
\hline
\end{tabular}

association between branches and performance importance is confirmed by a Chi-square test $(p<0.05)$.

\subsubsection{Drivers of EPE}

The main drivers for EPE in military units is the "prevention of health risks" (82\%) followed by "compliance with regulations" (79\%) (Table 2). Among the three branches, the Air Force and Navy follow the general pattern identified for the units overall. On the other hand, the main drivers identified by the Army are: "become a benchmark for the rest of the society" and the "commitment to social responsibilities", both with $94 \%$ of respondents, followed by several factors with $88 \%$, namely "image and reputation". The drivers of performance management, and in particular EPE, in private organizations may be quite different from public services. Public organizations pursue political and social goals rather than commercial and profit objectives. Public organizations must provide responses to the needs of society that are not covered by the private sector. Despite the significant differences between public and private sectors, the drivers most often identified by the respondents ("compliance with regulations", "to identify and mitigate environmental impacts", "to become a benchmark", "image and reputation") agree with trends reported by other authors (e.g. Refs. [47-52]), even though their main focus on private organizations. GEMI [52] presented the results of a business survey conducted by the National Association for Environmental Management showing that compliance with regulations is also one of the main drivers. However, as might be expected, the main two drivers identified by the respondent military units, "to preventing health risks" and "compliance with regulations", shows a different pattern in the respondents' priorities, when comparing with private organizations drivers. This result could be associated with the nature of public services, the military activities in particular and their related hazards and risks, as well as with the military compliance behaviour.

Table 2

Drivers of EPE in military units, as identified by the respondents

\begin{tabular}{llllr}
\hline Drivers of EPE & \multicolumn{4}{l}{ Respondents (\%) } \\
\cline { 2 - 6 } & $\begin{array}{l}\text { Portuguese } \\
\text { military sector }\end{array}$ & $\begin{array}{l}\text { Air } \\
\text { force }\end{array}$ & Army & \\
& 82 & 90 & 88 & 69 \\
& 79 & 90 & 88 & 62 \\
To prevent health risks & 77 & 70 & 88 & 69 \\
Compliance with regulations & 77 & 70 & 94 & 62 \\
To identify and mitigate environmental impacts & 77 & 40 & 88 & 46 \\
To become a benchmark & 62 & 50 & 94 & 31 \\
Image and reputation & 62 & 40 & 75 & 23 \\
Commitment to social responsibilities & 49 & 60 & 56 & 8 \\
To avoid environmental penalties & 41 & 30 & 44 & 38 \\
To improve stakeholders' participation & 38 & 30 & 63 & 8 \\
To increase mission/service/product efficiency & 36 & 30 & 56 & 8 \\
Innovative management & 33 & 20 & 38 & 38 \\
Expenditure reduction & 33 & 30 & 38 & 8 \\
To increase mission transparency & 26 & 10 & 25 & 0 \\
To increase credibility with stakeholders & 13 & 0 & 13 & 0 \\
To influence similar organizations & 5 & 0 & 6 & 0 \\
To respond to public pressure & 3 & &
\end{tabular}


The defence sector oversees a vast number of activities, products, services and facilities. While part of this activity is specifically military, such as weapons training, a large part is identical to civilian activity. Specific military activities generally have potential health effects, as studied by Phillips and Perry [53] and mentioned by Department of National Defence and the Canadian Forces (DND/CF) [20]. Nevertheless, as stressed by Carter et al. [54] much performance assessment goes beyond the public/private differences, reflecting characteristics which cut across this particular divide.

\subsubsection{ISO 14031 knowledge and implementation}

Only $22 \%$ of respondents know the ISO 14031 standard, which shows a generally poor knowledge. The Army units had the highest result, 47\%, showing a different pattern among the branches (Table 3). This association between branches and knowledge of ISO 14031 is confirmed by the Chi-square test $(p<0.01)$. This result could be an apparent contradiction with the fact of the Air Force being the branch that reveals overall best environmental results [40], with more environmental training and the commanders' and managers' environmental awareness, allowing the existence of many ongoing and/or already implemented environmental management practices. However, the Army highest knowledge level of ISO 14031 could be explained by the units surveyed in this branch being mainly represented by a small group with particular good environmental results (that accomplish the criteria used to select the units surveyed - having a person in charge of environmental issues). This fact does not show the branch overall picture. This branch presents a poor environmental profile, supported by an organizational structure with insufficiently defined environmental responsibilities, and a large number of units spread throughout the territory, which could lead to difficulties in managing environmental issues.

All the units in the Air Force and the Army that know the standard are planning to implement ISO 14031 in addition to an EMS, adopting ISO 14001 and/or the European regulation Environmental Management and Auditing Scheme (EMAS) (Table 3). The Navy unit that knows ISO 14031 states that the implementation will not be useful for the unit. This shows an important association between EMS and EPE, stating that respondents are aware of the different roles and potential advantages of both environmental management frameworks. It suggests to use ISO 14031 approach in addition to a formal EMS.

Dias-Sardinha et al. [55] asked 18 industrial and service Portuguese organizations about their strategic environmental objectives, their practices, and their EPE. This study showed that small and medium-sized companies do not seem to practise formal EPE, which is the general trend for Portuguese military units overall. However, these authors also stressed that EPE is common among

Table 3

Knowledge and implementation of ISO 14031 by the respondent units $(\mathrm{f}=$ frequency)

\begin{tabular}{|c|c|c|c|c|c|c|c|c|c|}
\hline \multirow[t]{2}{*}{ Question } & \multirow[t]{2}{*}{ Category label } & \multicolumn{2}{|c|}{ Air force } & \multicolumn{2}{|c|}{ Army } & \multicolumn{2}{|c|}{ Navy } & \multicolumn{2}{|c|}{ Total } \\
\hline & & $f$ & $\%$ & $f$ & $\%$ & $f$ & $\%$ & $f$ & $\%$ \\
\hline \multirow{5}{*}{$\begin{array}{l}\text { Knowledge of } \\
\text { ISO } 14031\end{array}$} & Yes & 2 & 15 & 8 & 47 & 1 & 5 & 11 & 22 \\
\hline & No & 11 & 85 & 9 & 53 & 20 & 95 & 40 & 78 \\
\hline & Nonresponses & 0 & & 0 & & 2 & & 2 & \\
\hline & Total & 13 & 100 & 17 & 100 & 21 & 100 & 51 & 100 \\
\hline & Chi-square test & \multicolumn{8}{|c|}{ Significant for $p<0.01$} \\
\hline \multirow{7}{*}{$\begin{array}{c}\text { Implementation } \\
\text { of ISO } 14031\end{array}$} & Yes, in addition to an EMS & 1 & 100 & 7 & 100 & 0 & 0 & 8 & 89 \\
\hline & Yes, instead of an EMS & 0 & 0 & 0 & 0 & 0 & 0 & 0 & 0 \\
\hline & No, not yet & 0 & 0 & 0 & 0 & 0 & 0 & 0 & 0 \\
\hline & No, not useful & 0 & 0 & 0 & 0 & 1 & 100 & 1 & 11 \\
\hline & Nonresponses & 1 & & 1 & & 0 & & 2 & \\
\hline & Total & 1 & 100 & 7 & 100 & 1 & 100 & 9 & 100 \\
\hline & Chi-square test & \multicolumn{8}{|c|}{ Not applicable $(n<30)$} \\
\hline
\end{tabular}

the larger industrial organizations surveyed, a result that is not reflected in the larger military units. In the public sector organization environmental performance assessment is quite new, with little literature available, despite some works that analyse the environmental measurement and communication in the public sector (e.g. Refs. [12-14,56]) and in the defence sector (e.g. Refs. $[20,22,25,57])$. Although the existence of some practice, these works don't give a complete overview of the public sector, as usually assessed for the corporate level.

\subsection{Environmental performance indicators}

\subsubsection{Knowledge and use of indicators}

The environmental indicator concept is mostly unknown for $63 \%$ of the people in charge of environmental issues in the units (Table 4). Once again, the Army shows a different result, with the reverse trend, with the majority of respondents (69\%) stating that they knew this tool. These results are reflected in the significant association between a knowledge of environmental indicators and the different branches $(p<0.01)$. The opposite trend to the current results was recorded by O'Reilly et al. [48] in their ISO 14031 study of 12 companies where the concept of environmental performance indicators was known. The military units that are implementing an EMS or have already implemented it are familiarized with this environmental tool, explaining some of the results obtained. In other countries that are conducting environmental and sustainability indicator initiatives for the public sector and for the defence (e.g. Refs. $[19,25]$ ), in particular, these results will probably be quite different, showing higher indicator knowledge and practice, despite no data available to do an accurate comparison. It should be stressed that environmental and sustainability indicators are becoming more known among Portuguese sectoral-ministries, excluding the defence. Every year the Ministry of the Environment produces the national State-of-Environment Report, which is based on indicators that need data from the different sectors. Sectorenvironment integration indicator is becoming a growing reality in

Table 4

Knowledge and use of environmental indicators by the respondent units ( $f=$ frequency)

\begin{tabular}{|c|c|c|c|c|c|c|c|c|c|}
\hline \multirow[t]{2}{*}{ Question } & \multirow[t]{2}{*}{ Category label } & \multicolumn{2}{|c|}{ Air force } & \multicolumn{2}{|c|}{ Army } & \multicolumn{2}{|c|}{ Navy } & \multicolumn{2}{|c|}{ Total } \\
\hline & & $f$ & $\%$ & $f$ & $\%$ & $f$ & $\%$ & $f$ & $\%$ \\
\hline $\begin{array}{l}\text { Knowledge of } \\
\text { environmental } \\
\text { indicators }\end{array}$ & $\begin{array}{l}\text { Yes } \\
\text { No } \\
\text { Nonresponses } \\
\text { Total } \\
\text { Chi-square test }\end{array}$ & $\begin{array}{r}6 \\
7 \\
0 \\
13 \\
\text { Sig }\end{array}$ & $\begin{array}{r}46 \\
54 \\
\\
100 \\
\text { ificant }\end{array}$ & $\begin{array}{r}11 \\
5 \\
1 \\
16 \\
\text { for } P\end{array}$ & $\begin{array}{l}69 \\
31 \\
100 \\
<0.0\end{array}$ & $\begin{array}{r}2 \\
20 \\
1 \\
22 \\
1\end{array}$ & $\begin{array}{r}9 \\
91\end{array}$ & $\begin{array}{r}19 \\
32 \\
2 \\
51\end{array}$ & $\begin{array}{l}37 \\
63\end{array}$ \\
\hline $\begin{array}{l}\text { Use of } \\
\text { environmental } \\
\text { indicators }\end{array}$ & $\begin{array}{l}\text { Yes } \\
\text { No } \\
\text { Nonresponses } \\
\text { Total } \\
\text { Chi-square test }\end{array}$ & $\begin{array}{c}5 \\
1 \\
1 \\
6 \\
\text { Not }\end{array}$ & $\begin{array}{c}83 \\
17 \\
\\
100 \\
\text { applic }\end{array}$ & $\begin{array}{r}5 \\
6 \\
2 \\
11 \\
\text { able }\end{array}$ & $\begin{array}{c}46 \\
55 \\
\\
100 \\
n<30\end{array}$ & $\begin{array}{r}1 \\
1 \\
4 \\
2 \\
0)\end{array}$ & $\begin{array}{r}50 \\
50 \\
100\end{array}$ & $\begin{array}{r}11 \\
8 \\
7 \\
19\end{array}$ & $\begin{array}{l}58 \\
42\end{array}$ \\
\hline $\begin{array}{l}\text { Optimal format } \\
\text { for indicators: } \\
\text { internal } \\
\text { stakeholders }\end{array}$ & $\begin{array}{l}\text { Absolute or original } \\
\text { values } \\
\text { Normalized values } \\
\text { Adimensional or } \\
\text { aggregated values } \\
\text { Nonresponses } \\
\text { Total } \\
\text { Chi-square test }\end{array}$ & $\begin{array}{l}6 \\
7\end{array}$ & $\begin{array}{l}86 \\
14 \\
43\end{array}$ & $\begin{array}{r}1 \\
4 \\
\\
6 \\
11 \\
\text { ble }\end{array}$ & $\begin{array}{r}9 \\
36\end{array}$ & $\begin{array}{r}10 \\
13 \\
0)\end{array}$ & $\begin{array}{l}38 \\
23\end{array}$ & $\begin{array}{l}22 \\
31\end{array}$ & $\begin{array}{l}23 \\
32\end{array}$ \\
\hline $\begin{array}{l}\text { Optimal format } \\
\text { for indicators: } \\
\text { external } \\
\text { stakeholders }\end{array}$ & $\begin{array}{l}\text { Absolute or original } \\
\text { values } \\
\text { Normalized values } \\
\text { Adimensional or } \\
\text { aggregated values } \\
\text { Nonresponses } \\
\text { Total } \\
\text { Chi-square test }\end{array}$ & $\begin{array}{c}7 \\
6 \\
\text { Not }\end{array}$ & $\begin{array}{r}0 \\
50\end{array}$ & $\begin{array}{r}7 \\
10 \\
\text { ble }\end{array}$ & $\begin{array}{r}0 \\
40\end{array}$ & $\begin{array}{l}12 \\
11 \\
0)\end{array}$ & $\begin{array}{l}45 \\
55\end{array}$ & $\begin{array}{l}26 \\
27\end{array}$ & $\begin{array}{l}19 \\
48\end{array}$ \\
\hline
\end{tabular}


several domains, such as transport, enterprise and agriculture. Despite their social, environmental and economic importances, the overall public sector and the defence, in particular, are always omitted in the national State-of-Environment Report or in the related initiatives.

About half the units that do know about environmental indicators use them (58\%). However, the Air Force reflects a more positive trend: $71 \%$ of these units are using indicators (Table 4 ). However, the association between military branches and the use of environmental indicators is not significant. The study of Dias-Sardinha et al. [55] showed that $50 \%$ of respondents companies mentioned that they use, or will use, environmental performance indicators. This generally matches what we found in our study. These results should be analysed with caution, since very frequently organizations use different and wrong concepts for indicators. The terminology used in the area is still quite confusing and is not well established, leading to misinterpretations. As stated by United Nations Environment Programme and National Institute of Public Health and the Environment (UNEP/RIVM) [58], the term "indicator" is sometimes used rather loosely to include almost any sort of quantitative information.

Environmental indicators are mainly used in mission/activity reports (70\% of respondents that use indicators), environmental reports (60\%) and newsletters (40\%). Despite these results it was possible to ascertain that the "environmental reports" identified by many respondents diverge quite significantly from the practice of environmental and sustainability reporting by public and private organizations. "Environmental reports" produced by the units are mainly for internal use and have an informal structure. They relate specially to solid waste, wastewater and water supply data.

\subsubsection{The optimal format for indicators}

The units point to several factors as the main elements for the design of environmental indicator results in the military, especially regarding the optimal format for the indicators, for internal and external stakeholders. Most respondents stated that indicators should be reported in association with the different types of mission/activity, with objectivity and precision, in a realistic and understandable way for the target audience, and with the easiest computation. Raw data can be manipulated in several ways to produce indicator results. In general, more units stated that indicators should be expressed in absolute or original values $(61 \%$ of respondents) for internal stakeholders (e.g. inside the military unit or for the MDN services) (Table 4). Adimensional or aggregated values (48\%), e.g. using environmental indices, and original values (48\%) should be the most appropriate way of expressing the indicators, when dealing with external stakeholders (e.g. local communities, nongovernmental organizations, municipalities, schools and journalists). In general, the trend is the same among the branches. The use of aggregated information, as stated in many responses, could be justified by the strict military profile, restricting the detail of the information communicated to the external parties concerned. Bennett and James [3] stated within their study that $45 \%$ of survey respondents reported that they were using relative (in the ISO use of the term) or normalized indicators. They also reported difficulties in determining the best way to calculate the indicator, i.e. the most appropriate measure of business to use as the denominator, in a ratio in which the environmental measure is the numerator.

\subsubsection{The advantages and drawback/limitations of using indicators}

The main advantages identified by the units for using environmental indicators are that they "help in decision-making processes" (72\%), "allow a continuous assessment of the environmental performance" (67\%) and "facilitate control of the environmental compliance regulations" (61\%) (Table 5). These results show
Table 5

The main advantages and limitations/drawbacks of using environmental indicators, as identified by the respondent units

\begin{tabular}{|c|c|c|c|}
\hline Advantages & $\begin{array}{l}\text { Respondents } \\
(\%)\end{array}$ & Limitations/drawbacks & $\begin{array}{l}\text { Respondents } \\
(\%)\end{array}$ \\
\hline $\begin{array}{l}\text { They help in decision- } \\
\text { making processes }\end{array}$ & 72 & $\begin{array}{l}\text { Lack of environmentally } \\
\text { specialized human } \\
\text { resources in the unit }\end{array}$ & 61 \\
\hline $\begin{array}{l}\text { They allow } \\
\text { a continuous } \\
\text { assessment of } \\
\text { environmental } \\
\text { performance }\end{array}$ & 67 & $\begin{array}{l}\text { Lack of environmental } \\
\text { monitoring data }\end{array}$ & 44 \\
\hline $\begin{array}{l}\text { They facilitate control } \\
\text { of environmental } \\
\text { compliance } \\
\text { regulations }\end{array}$ & 61 & $\begin{array}{l}\text { Lack of rigorous criteria to } \\
\text { support indicator selection } \\
\text { and development }\end{array}$ & 39 \\
\hline $\begin{array}{l}\text { They provide support } \\
\text { for environmental } \\
\text { reports }\end{array}$ & 50 & $\begin{array}{l}\text { Absence of an } \\
\text { environmental } \\
\text { management system }\end{array}$ & 33 \\
\hline $\begin{array}{l}\text { They identify priority } \\
\text { areas and stress } \\
\text { trends }\end{array}$ & 44 & $\begin{array}{l}\text { Difficult association } \\
\text { between theoretical } \\
\text { indicator limits and } \\
\text { environmental regulations }\end{array}$ & 28 \\
\hline $\begin{array}{l}\text { They synthesize } \\
\text { technical } \\
\text { environmental data }\end{array}$ & 39 & $\begin{array}{l}\text { Absence of environmental } \\
\text { management practices }\end{array}$ & 22 \\
\hline $\begin{array}{l}\text { They identify key } \\
\text { environmental } \\
\text { variables }\end{array}$ & 39 & $\begin{array}{l}\text { Loss of information in data } \\
\text { aggregation processes }\end{array}$ & 11 \\
\hline $\begin{array}{l}\text { They facilitate data } \\
\text { communication }\end{array}$ & 39 & $\begin{array}{l}\text { Possibility of an excessive } \\
\text { information relay to } \\
\text { external parties }\end{array}$ & 11 \\
\hline- & - & $\begin{array}{l}\text { Identification of the best } \\
\text { algorithm to transform raw } \\
\text { data into aggregated } \\
\text { indicators (indexes) }\end{array}$ & 6 \\
\hline
\end{tabular}

a certain concordance with the findings registered by O'Reilly et al. [48] for companies in the UK. On the other hand the limitations and drawbacks of using indicators are the lack of environmentally specialized human resources in the unit (61\%) and the lack of environmental monitoring data (44\%). This result is justified by the few staff members in charge of all environmental areas, which the majority does not have any kind of environmental training, as verified by Ramos and Melo [40]. These limitation factors are also applicable to a broader context of the Portuguese reality, especially for small and medium organizations that are still distant from environmental and sustainability concerns and practices.

\subsection{SEPE index by service branch}

SEPE index results for the Portuguese military sector show that the knowledge, awareness and practice of EPE in the Portuguese military are almost new issues, presenting a medium state of environmental performance (0.43), classified according to the index classes (Fig. 1). The Army has the highest value (0.63), revealing the best result among the three branches. These differences between EPE and the military branches were confirmed by the results of the Kruskal-Wallis test (significant for $p<0.01$ ). Differences among regions are non-significant. Correlation between SEPE and unit dimension (land area and personnel) is also not significant.

An ongoing implementation process of EMS in several of the Army units surveyed, integrated in the Campo Militar de Santa Margarida (35\% of the Army respondents), a military training camp, could explain these better results. The Air Force also has several ongoing and/or already implemented environmental management practices in place under the Air Force environmental policy that has been adopted. This could explain their positive results. It was foreseeable, though, that the Air Force would present higher results 


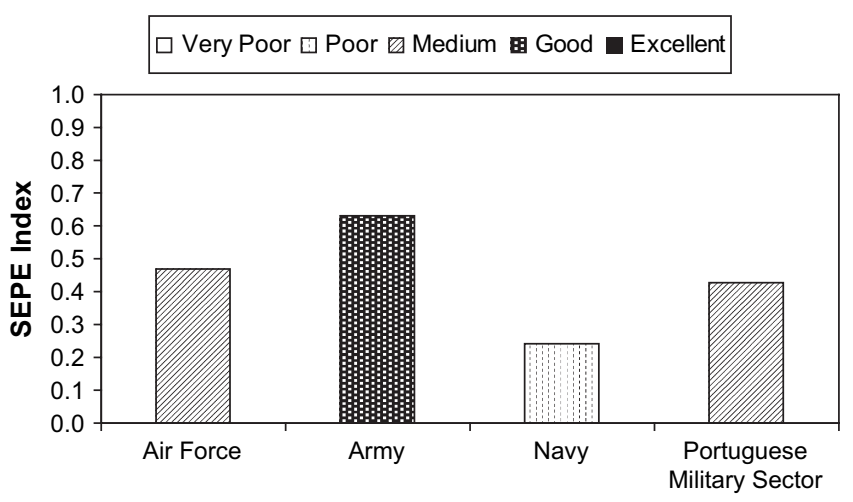

Sector and Military Branches

Fig. 1. Index of the state of environmental performance evaluation (SEPE) for the Portuguese military sector and the three military branches.

in accordance with its top profile of environmental management practices among the three branches. Also, earlier work, [40], proving better environmental training initiatives in the Army and Air Force could justify the lower state of EPE in the Navy. Since military units with a person in charge of environmental issues were the only ones surveyed, some of the worst cases may have been excluded. It must be also stressed that the Army is the biggest military branch and few units have an environmental coordinator/ delegate, in contrast to the Air Force where all the units have a person in charge of environmental issues. The Army results may thus be biased.

No similar works are available for other countries' armed forces, i.e. studies that analyse the state of knowledge, awareness and practice of this particular management practice, EPE, among the main military branches at a national level. Despite this, some attempts to make comparisons with other military forces have been carried out. Several works show that some countries are developing efforts to put in practice sustainability and/or environmental performance assessment. For example, the Canada defence sector proposed performance measures that were developed by the Committee on Performance Measurement for Sustainable Government Operations (PMSGO) [56]. These measures were adapted by the Department of National Defence and Canadian Forces (DND/ CF) $[20,22,57]$ as an integral component of the department's overall performance measurement process, by which they measure and report the department's progress in meeting its sustainable development commitments. The Australian Department of Defence (Australian DoD) [21] proposed an environmental performance reporting framework, by which defence (corporately and at the site level) reports the EMS performance management requirements (monitoring, measurement and auditing, and management review). Other countries, such as United Sates of America, South Africa, Netherlands and United Kingdom, are developing similar initiatives, generally associated to a sustainable development strategy for the public sector.

This approach, the assessment through the SEPE index, tries to help the defence decision-makers to understand the military profile, regarding the EPE tool. The MDN is beginning to improve the current state of EPE, as a major part of environmental management practices overall. MDN services intend to build an information system to storage and analyse military unit's environmental performance data, driving organizations for the implementation of performance assessment tools. Although there are few EPE related initiatives implemented in the Portuguese military, the sector presents signs of improvement, despite it's isolation from the rest of the public sector, which have a small number of environmental and sustainability initiatives. In this context, should be stressed that there is no sustainable government strategy or environmental performance assessment program for the Portuguese public services.

\section{Conclusions}

EPE is growing very rapidly, in particular, in private organizations. Despite various initiatives driving environmental management practices in public sector, most of that experience is only centred on an EMS, and EPE is quite a new issue. The defence sector is not an exception. However, as indicated by the results, Portuguese military units agree on the importance of evaluating environmental performance.

The main drivers for EPE in military units are the prevention of health risks and compliance with regulations. This pattern could reflect the nature of the sector's activities and its related hazards.

ISO 14031 and environmental indicators are almost unknown concepts for the respondent military units, despite some differences among branches. The Army presents the best results, probably justified by the following factors: (i) an ongoing implementation process of EMS in several of the Army units surveyed (35\% of the Army respondents); (ii) an increasing number of environmental training initiatives; and (iii) the bias induced by the criteria used to select the units surveyed (having a person in charge of environmental issues).

The units surveyed do not seem to practise formal EPE, even though all the units in the Air Force and Army that know the ISO 14031 standard are planning to implement it, along with EMS. The use of environmental indicators is a reality for about half the units, which shows a fair development in the use of this management tool.

Environmental indicators are mainly used in mission/activity reports, environmental reports and newsletters. However, the general pattern of "environmental reports" identified by many respondents is poorer than corporate environmental reporting practice. Most respondents stated that indicators should be reported in association with the different types of mission/activity. The considerations that they help in decision-making processes and allow a continuous assessment of environmental performance are the main advantages reported by the respondents for using environmental indicators.

For the future it's important to retain that ISO 14031 could be especially suitable for small and medium enterprises (SMEs), because it can be carried out and maintained event with scarce personnel and financial resources, as concluded in the pilot study project in Germany cited by O'Reilly et al. [48]. This finding is of particular interest as military Portuguese units are almost comparable to SMEs. As stressed by the same authors, organizations have found that the requirement of certifiable EMSs can be over burdensome, and ISO 14031 can add real tangible, value, by focusing on priority domains of environmental performance.

An index - SEPE - was used to demonstrate the overall state of EPE in the Portuguese military sector. This tool gave the aggregated result for the knowledge, awareness and practice of EPE in the units, showing that these issues are quite recent within the defence domain. It must be stressed that the methodology used does not aim to rank individual respondent units. This kind of tool could be used by defence services in the future to collect and aggregate environmental data, contributing to the communication and the assessment of the state of the defence sector-environmental profile, and helping decision-makers to track policies' outcomes.

The results of this work provide important support for the future development of EPE practices, including, in particular, performance indicators within the defence sector. By assessing the state of EPE for this sector, it will be easier to address the sector's particular sensitivities and implement the most appropriate EPE framework. 


\section{Acknowledgements}

We would like to express our thanks for the support of the MDN. The first author had a PRAXIS XXI/BD/15973/98 scholarship, financed by the ESF (European Social Fund). We would like also to acknowledge the invaluable collaboration of Ms. Isabel Leitão and Mr. Álvaro Estrela Soares from the MDN.

Appendix.

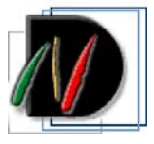

Portuguese Ministry of Defence Directorate- General of Infrastructures

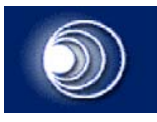

University of the Algarve Faculty of Marine and Environmental Science

\section{ENVIRONMENTAL ASPECTS, IMPACTS AND INDICATORS OF THE PORTUGUESE DEFENCE SECTOR:}

\section{QUESTIONNAIRE SURVEY}

\section{IDENTIFICATION}

\section{Unit Name}

Phone

Fax

E-mail

Address

Postal Code

Municipality

NUTS II

Açores

Alentejo

Algarve

Centro.

Lisboa e Vale do Tejo

Norte...

Madeira

Main Mission

Personnel (number)

\section{Military branch}

Navy.

Army....

Air force

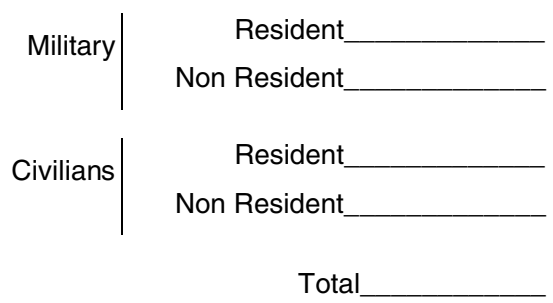




\section{ACTIVITIES; ASPECTS AND IMPACTS}

1. (a) Please mark with a cross the main activities conducted in your Unit

(b) Activities in a military unit could cause significant environmental problems Please assign the importance level ( $1=$ low; $2=$ medium; $3=$ high) relative to each problem identified in (a).

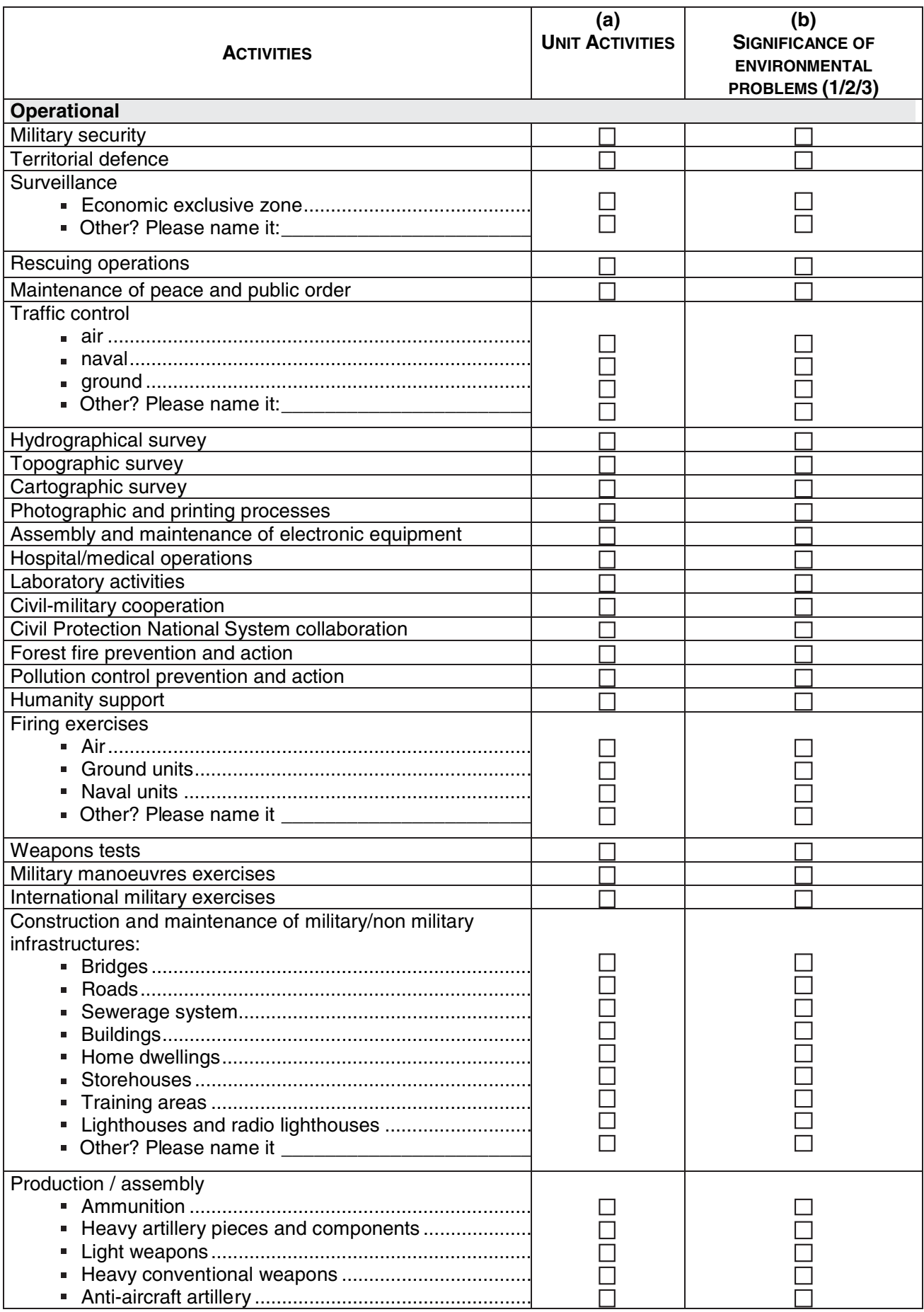




\begin{tabular}{|c|c|c|}
\hline Activities & $\begin{array}{c}\text { (a) } \\
\text { UNIT ACTIVITIES }\end{array}$ & $\begin{array}{c}\text { (b) } \\
\text { SIGNIFICANCE OF } \\
\text { ENVIRONMENTAL } \\
\text { PROBLEMS }(1 / 2 / 3)\end{array}$ \\
\hline 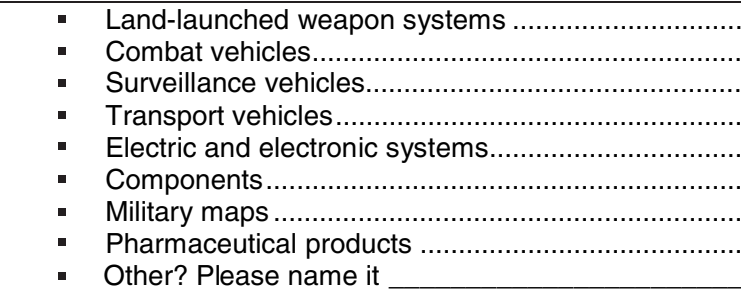 & $\begin{array}{l}\square \\
\square \\
\square \\
\square \\
\square \\
\square \\
\square \\
\square \\
\square\end{array}$ & $\begin{array}{l}\square \\
\square \\
\square \\
\square \\
\square \\
\square \\
\square \\
\square \\
\square\end{array}$ \\
\hline $\begin{array}{l}\text { Maintenance and repair: } \\
\text { : } \quad \text { Heavy artillery pieces and components } \\
\text { - } \quad \text { Heavy ammunition }\end{array}$ & $\begin{array}{l}\square \\
\square \\
\square \\
\square \\
\square \\
\square \\
\square \\
\square \\
\square \\
\square \\
\square \\
\square \\
\square\end{array}$ & $\begin{array}{l}\square \\
\square \\
\square \\
\square \\
\square \\
\square \\
\square \\
\square \\
\square \\
\square \\
\square \\
\square\end{array}$ \\
\hline $\begin{array}{l}\text { Decommissioning / demilitarization } \\
\text { : } \text { Heavy artillery pieces and components . }\end{array}$ & $\begin{array}{l}\square \\
\square \\
\square \\
\square \\
\square \\
\square \\
\square \\
\square \\
\square \\
\square \\
\square\end{array}$ & $\begin{array}{l}\square \\
\square \\
\square \\
\square \\
\square \\
\square \\
\square \\
\square \\
\square \\
\square \\
\square\end{array}$ \\
\hline Wastewater drainage and treatment & $\square$ & $\square$ \\
\hline Water treatment and supply & $\square$ & $\square$ \\
\hline Pest control management & $\square$ & $\square$ \\
\hline Green space management & $\square$ & $\square$ \\
\hline Waste Management & $\square$ & $\square$ \\
\hline Others? Please name it & $\square$ & $\square$ \\
\hline \multicolumn{3}{|l|}{ Management/Administration } \\
\hline Management/Administration & $\square$ & $\square$ \\
\hline \multicolumn{3}{|l|}{ Military instruction and training } \\
\hline Higher education & $\square$ & $\square$ \\
\hline Scientific research & $\square$ & $\square$ \\
\hline Others? Please name it & $\square$ & $\square$ \\
\hline \multicolumn{3}{|l|}{ Logistics operations } \\
\hline 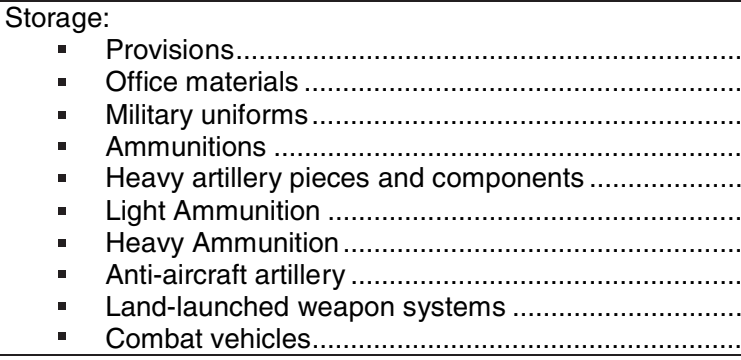 & $\begin{array}{l}\square \\
\square \\
\square \\
\square \\
\square \\
\square \\
\square \\
\square \\
\square \\
\square\end{array}$ & $\begin{array}{l}\square \\
\square \\
\square \\
\square \\
\square \\
\square \\
\square \\
\square \\
\square\end{array}$ \\
\hline
\end{tabular}




\begin{tabular}{|c|c|c|}
\hline ACTIVITIES & $\begin{array}{c}\text { (a) } \\
\text { UNIT ACTIVITIES }\end{array}$ & $\begin{array}{c}\text { (b) } \\
\text { SIGNIFICANCE OF } \\
\text { ENVIRONMENTAL } \\
\text { PROBLEMS }(1 / 2 / 3)\end{array}$ \\
\hline 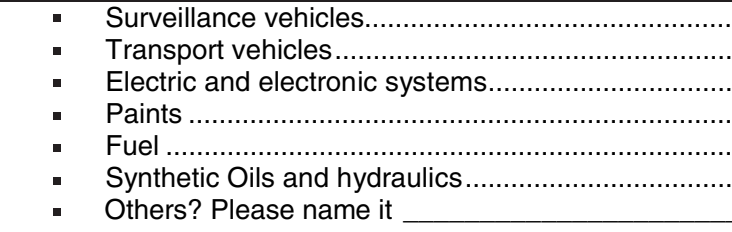 & $\begin{array}{l}\square \\
\square \\
\square \\
\square \\
\square \\
\square \\
\square\end{array}$ & $\begin{array}{l}\square \\
\square \\
\square \\
\square \\
\square \\
\square \\
\square\end{array}$ \\
\hline Military transport (air, ground and naval) & $\square$ & $\square$ \\
\hline Refuelling operations & $\square$ & $\square$ \\
\hline Other? Please name it & $\square$ & $\square$ \\
\hline
\end{tabular}

2. Please answer the following questions considering your answer at question 1 :

(a) Identify the environmental aspects associated with the activities in your unit, and assign their significance/relevance

Note: environmental aspect - unit's activities, products and services (or parts therefore) that may influence the environment. A significant environmental aspect is an environmental aspect that has or can have a significant environmental impact.

Environmental impact: any change to the environment, whether adverse or beneficial, wholly or partially resulting from a unit's activities, products or services.

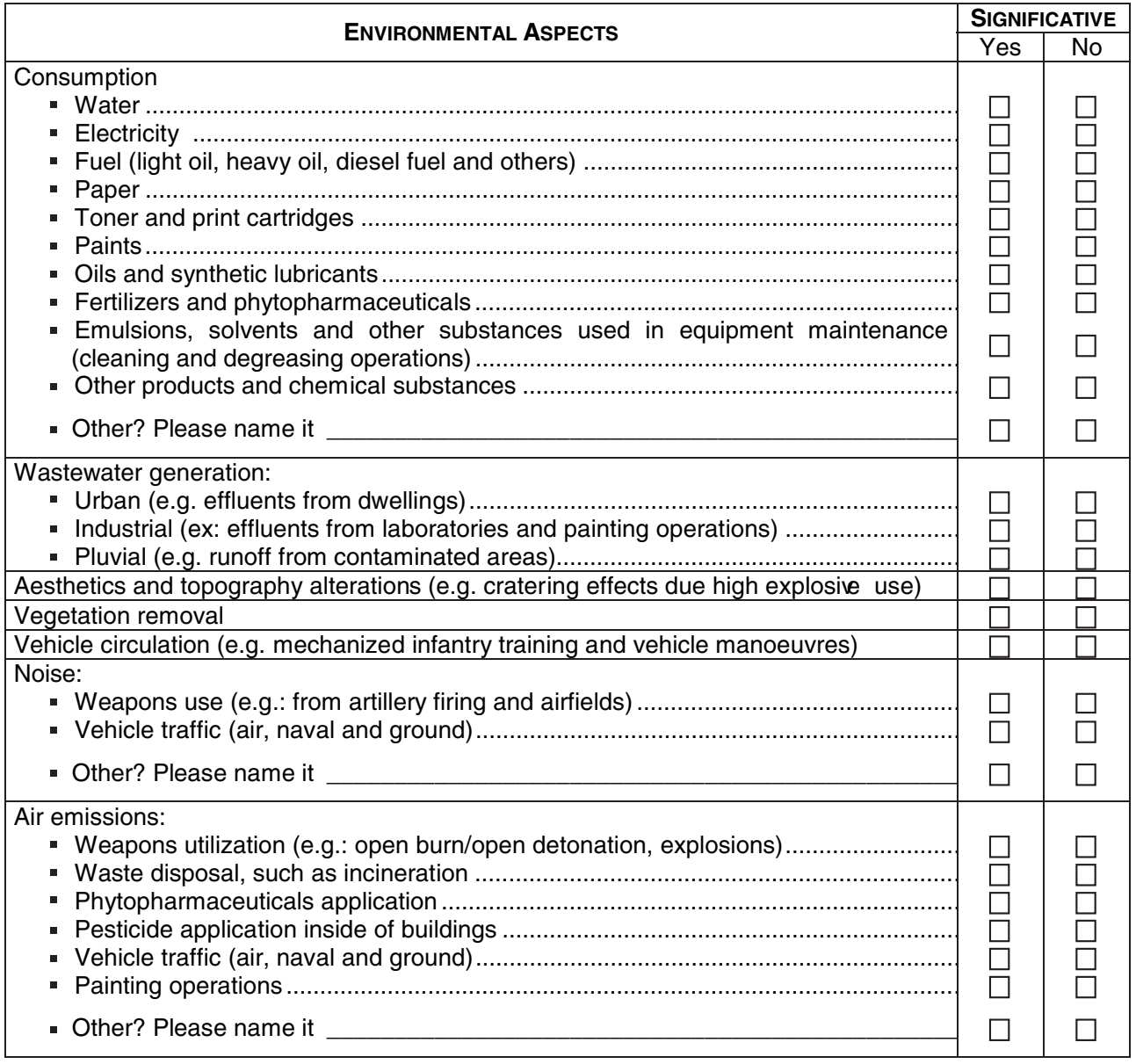




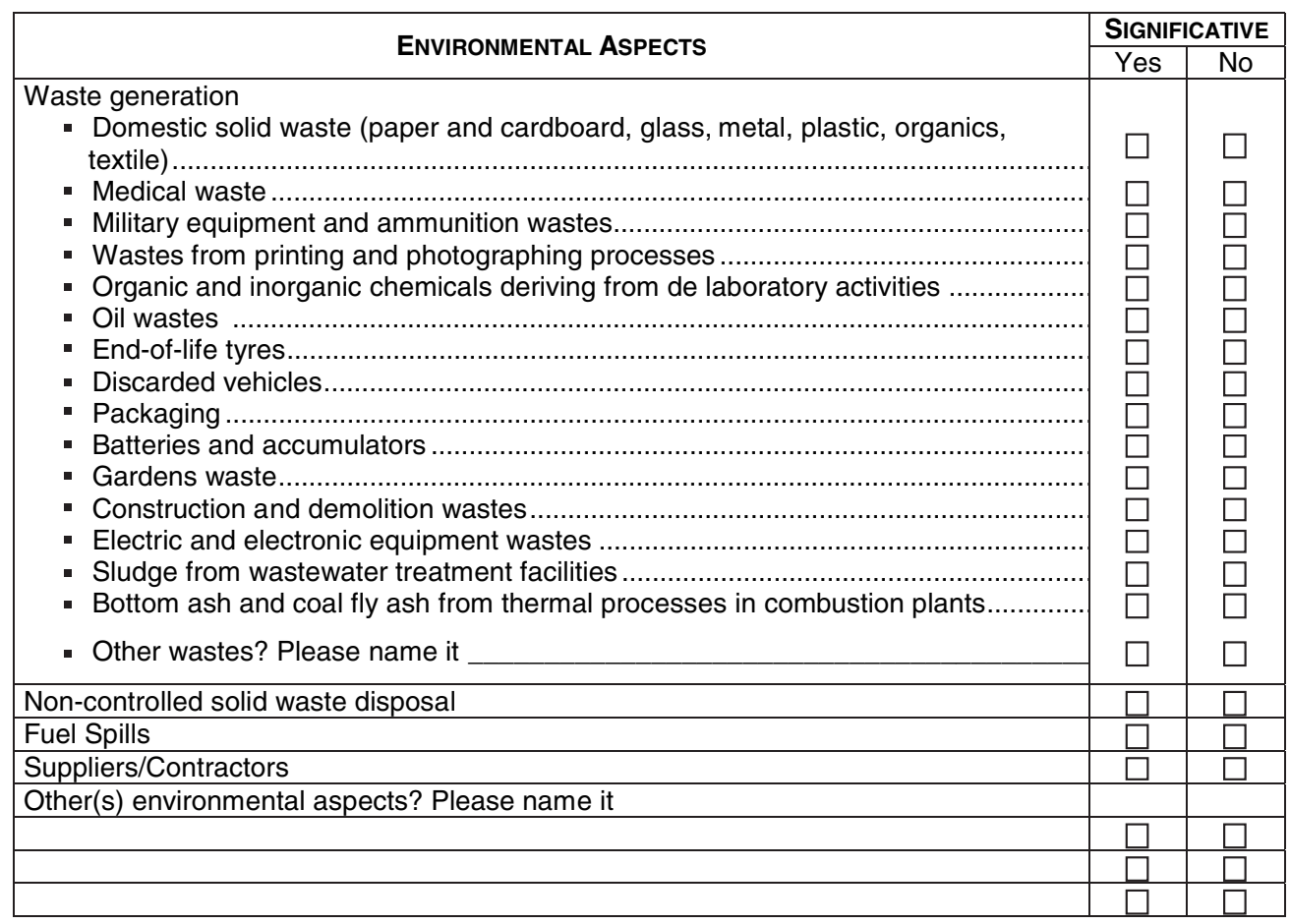

(b) Identify the negative environmental impacts associated with the environmental aspects identified below (at question 2 (a)) and assign their significance above (please, mark with a cross)

\begin{tabular}{|c|c|c|}
\hline \multirow[b]{2}{*}{ ENVIRONMENTAL IMPACTS } & \multicolumn{2}{|c|}{ SIGNIFICATIVE } \\
\hline & Yes & No \\
\hline \multicolumn{3}{|l|}{ Water quality and hydrological resources impacts } \\
\hline Changes on surface water quality & $\square$ & $\square$ \\
\hline Changes on groundwater quality & $\square$ & $\square$ \\
\hline $\begin{array}{l}\text { Hydrological alterations (alteration on channel form due to changes in landforms, } \\
\text { vegetation clearance and soil compaction; sedimentation of rivers) }\end{array}$ & $\square$ & $\square$ \\
\hline $\begin{array}{l}\text { Groundwater alterations (e.g. water table modification, depth to water table, } \\
\text { permeability, location of recharge area) }\end{array}$ & $\square$ & $\square$ \\
\hline \multicolumn{3}{|l|}{ Soil Impacts } \\
\hline Soil contamination & $\square$ & $\square$ \\
\hline - acidification & $\square$ & $\square$ \\
\hline - salinity & $\square$ & $\square$ \\
\hline Soil compaction & $\square$ & $\square$ \\
\hline Lost/perturbation of arable soil & $\square$ & $\square$ \\
\hline Soil impermeabilization & $\square$ & $\square$ \\
\hline Soil erosion & $\square$ & $\square$ \\
\hline Land use/soil occupation & $\square$ & $\square$ \\
\hline \multicolumn{3}{|l|}{ Climate and Air Quality Impacts } \\
\hline Effects on temperature, humidity and wind-speed & $\square$ & $\square$ \\
\hline Effects on local climate & $\square$ & $\square$ \\
\hline Indoor air quality effects & $\square$ & $\square$ \\
\hline Air quality deterioration & $\square$ & $\square$ \\
\hline \multicolumn{3}{|l|}{ Impacts on ecosystems } \\
\hline Habitats destruction & $\square$ & $\square$ \\
\hline Vegetation destruction & $\square$ & $\square$ \\
\hline Biotic communities disturbance (e.g. invasion of exotic species) & $\square$ & $\square$ \\
\hline Biodiversity lost & $\square$ & $\square$ \\
\hline \multicolumn{3}{|l|}{ Landscape and patrimonial Impacts } \\
\hline Landscape alterations & $\square$ & $\square$ \\
\hline $\begin{array}{l}\text { Cultural heritage degradation (e.g. Archaeological sites and structures, historic } \\
\text { properties) }\end{array}$ & $\square$ & $\square$ \\
\hline
\end{tabular}




\begin{tabular}{|c|c|c|}
\hline \multicolumn{1}{|c|}{ ENVIRONMENTAL IMPACTS } & SIGNIFICATIVE \\
\hline \multicolumn{1}{|c|}{ Socio-Economics Impacts } & Yes & No \\
\hline Human health effects & & \\
\hline Local and regional economic effects & $\square$ & $\square$ \\
\hline Alterations on socio-economic, cultural and local communities well-being structures & $\square$ & $\square$ \\
\hline Other impacts? Please, name it & & $\square$ \\
\hline & $\square$ & $\square$ \\
\hline & $\square$ & $\square$ \\
\hline$\square$ & $\square$ \\
\hline$\square$ & $\square$ \\
\hline
\end{tabular}

(b) In the significance evaluation at the questions (2a) (2b) what were the main aspects that induced your answer? Please mark $(\mathrm{X})$

Legal constraints

$\square$ Potential human health hazard/risk

Potential environment hazard/risk

Hygiene and safety work conditions at unit

Guidelines from military commands or Ministry of Defence

Pressure from stakeholders (e.g.: local communities; nongovernmental organizations)

Pressure from suppliers

$\square$ Pressure from insurance companies

$\square$ Pressures from decision makers

$\square$ Economic motivations

$\square$ Other(s)

(d) Has been already identified the environmental aspects and impacts associated with the activities developed in your unit.

Yes $\square$ No $\square$

(e) If so, in the identification process was used a formal procedure?

$\square$ Yes?, please name it

$\square$ No

(f) Characterize the environmental impacts identified as significative at question 2 (b) considering the following properties:

${ }^{1}$ Extent l: total (whole unit area)

P: partial (specific sites within the unit area)

E: exterior (e.g. external to the unit)

${ }^{2}$ Frequency: T: temporary

P: permanent

${ }^{3}$ Source D: direct (caused directly by unit's activities)

I: indirect (caused indirectly by unit's activities)

${ }^{4}$ Magnitude $\mathrm{VH}$ : very high

- intensity or extent of the $\mathrm{H}$ : high

alteration: M: medium

W: weak

VW: very weak 


\begin{tabular}{|c|c|c|c|c|}
\hline \multirow{2}{*}{ ENVIRONMENTAL IMPACTS } & \multicolumn{4}{|c|}{ IMPACTS PROPERTIES } \\
\hline & EXTENT $^{1}$ & FREQUENCY $^{2}$ & SOURCE $^{3}$ & MAGNITUDE $^{4}$ \\
\hline \multicolumn{5}{|l|}{ Water resources and quality } \\
\hline \multicolumn{5}{|l|}{ Changes on surface water quality } \\
\hline \multicolumn{5}{|l|}{ Changes on groundwater quality } \\
\hline \multicolumn{5}{|l|}{$\begin{array}{l}\text { Hydrological alterations (alteration on channel form } \\
\text { due to changes in landforms, vegetation clearance } \\
\text { and soil compaction; sedimentation of rivers) }\end{array}$} \\
\hline \multicolumn{5}{|l|}{$\begin{array}{l}\text { Groundwater alterations (e.g. water table } \\
\text { modification, depth to water table, permeability, } \\
\text { location of recharge area) }\end{array}$} \\
\hline \multicolumn{5}{|l|}{ Soil } \\
\hline \multicolumn{5}{|l|}{ Soil contamination } \\
\hline \multicolumn{5}{|l|}{ acidification } \\
\hline \multicolumn{5}{|l|}{ - salinity } \\
\hline \multicolumn{5}{|l|}{ Soil compaction } \\
\hline \multicolumn{5}{|l|}{ Loss of arable soil } \\
\hline \multicolumn{5}{|l|}{ Soil impermeabilization } \\
\hline \multicolumn{5}{|l|}{ Soil erosion } \\
\hline \multirow{2}{*}{\multicolumn{5}{|c|}{$\begin{array}{l}\text { Land use/soil occupation } \\
\text { Climate and air quality }\end{array}$}} \\
\hline & & & & \\
\hline \multicolumn{5}{|l|}{ Effects on temperature, humidity and wind-speed } \\
\hline \multicolumn{5}{|l|}{ Effects on local climate } \\
\hline \multicolumn{5}{|l|}{ Indoor air quality effects } \\
\hline \multicolumn{5}{|l|}{ Air quality deterioration } \\
\hline \multicolumn{5}{|l|}{ Ecosystems } \\
\hline \multicolumn{5}{|l|}{ Habitats destruction } \\
\hline \multicolumn{5}{|l|}{ Vegetation destruction } \\
\hline \multicolumn{5}{|l|}{$\begin{array}{l}\text { Biotic communities disturbance (e.g. invasion of } \\
\text { exotic species) }\end{array}$} \\
\hline \multirow{2}{*}{\multicolumn{5}{|c|}{$\begin{array}{l}\text { Biodiversity lost } \\
\text { Landscape and heritage }\end{array}$}} \\
\hline & & & & \\
\hline \multicolumn{5}{|l|}{ Landscape alterations } \\
\hline \multicolumn{5}{|l|}{$\begin{array}{l}\text { Cultural heritage degradation (e.g. archaeological } \\
\text { sites and structures, historic properties) }\end{array}$} \\
\hline Social and economic & & & & \\
\hline Human health effects & & & & \\
\hline Local and regional economic effects & & & & \\
\hline $\begin{array}{l}\text { Alterations on socio-economic, cultural and local } \\
\text { communities well-being structures }\end{array}$ & & & & \\
\hline Other & & & & \\
\hline & & & & \\
\hline & & & & \\
\hline & & & & \\
\hline & & & & \\
\hline & & & & \\
\hline & & & & \\
\hline
\end{tabular}




\section{ENVIRONMENTAL PERFORMANCE AND INDICATORS}

3. (a) Does your unit consider important and necessary to conduct environmental performance evaluation and communication?

Yes $\square$ No $\square$ Don’t know $\square$

(b) If so, identify the main drivers which justify the need to evaluate and communicate the environmental performance of your unit

\begin{tabular}{|l|ll|}
\hline$\square$ To promote image and reputation & $\square$ & To become a benchmark \\
$\square$ Innovative management & $\square$ Commitment to social responsibilities \\
\hline $\begin{array}{l}\text { To identify and mitigate environmental } \\
\text { impacts resulting from organization activities }\end{array}$ & $\square$ To improve stakeholders' participation in \\
Unit activities
\end{tabular}

4. (a) Is the unit's persons in charge of environmental issues familiar with the ISO 14031 standard on "environmental performance evaluation"? Yes $\square$ No $\square$

(b) If so (to a), has or will the unit implement this standard?

Yes, in addition to an environmental management system (ISO 14001 e/ou EMAS)

Yes, instead of an environmental management system

No, not yet set out

No, it will not be useful for the Unit

5. (a) Is the unit's persons in charge of environmental issues familiar with the "environmental indicator" concept?

Yes $\square$ No $\square$

If so (to a), please answer the following questions:

(b) Are environmental indicators used in your unit?

Yes $\square$ No

(b.1) If so, identify the type of report where you use environmental indicators

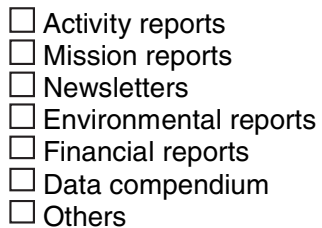

(b.2) Please, introduce the reference of this report (if possible, send a copy of the report or part(s) which are used environmental indicators).

Report's Reference 
(c) Environmental indicators can be expressed in three distinct ways:

- Absolute or original values (e.g. "water consumption": $\mathrm{m}^{3}$.year ${ }^{-1}$ );

- Normalized (e.g. "water consumption": $\mathrm{m}^{3} / \mathrm{misson} ; \mathrm{m}^{3} / \mathrm{maps}$ printed or $\mathrm{m}^{3} /$ service provided);

- Aggregated, resulting in a classification scale (e.g.: "water consumption": class A - high water consumption; class $\mathrm{B}$ - moderate water consumption; class $\mathrm{C}$ - low water consumption))

What physical units do you consider more appropriate to report indicators for internal stakeholders (e.g. inside your unit, among another branches of armed forces or Portuguese Ministry of Defence)? Please check the option(s) you've considered more appropriated.

$\square$ Absolute or original values

Aggregate values

Please, justify your answer

What units do you consider more appropriate to report indicators for external stakeholders (e.g. local communities, nongovernmental organizations, municipalities, schools and journalists)? Please check the option(s) you've considered more appropriated.

$\square$ Absolute or original values

Normalized values

$\square$ Aggregate values

Please, justify your answer

(d) Please, identify the main advantages and limitations/drawbacks of using environmental indicators in your Unit

\begin{tabular}{|c|c|}
\hline Advantages & Limitations/Drawbacks \\
\hline $\begin{array}{l}\square \text { To synthesize technical environmental data; } \\
\square \text { To identify key environmental variables; } \\
\square \text { To facilitate data communication; } \\
\square \text { To help in decision-making processes; } \\
\square \text { To identify priority areas and stress trends; } \\
\square \text { To provide support for environmental reports; } \\
\square \text { To facilitate control of environmental compliance } \\
\text { regulations; } \\
\square \text { To allow a continuous assessment of } \\
\text { environmental performance. }\end{array}$ & $\begin{array}{l}\square \text { Lack of environmental monitoring data; } \\
\square \text { Identification of the best algorithm to transform } \\
\text { raw data into aggregated indicators (indexes); } \\
\square \text { Loss of information in data aggregation } \\
\text { processes; } \\
\square \text { Difficult association between theoretical Indicator } \\
\text { limits and environmental regulations; } \\
\square \text { Lack of rigorous criteria to support indicator } \\
\text { selection and development; } \\
\square \text { Absence of environmental management } \\
\text { practices; } \\
\square \text { Absence of an environmental management } \\
\text { system; } \\
\square \text { Lack of environmentally specialized human } \\
\text { resources in the unit; } \\
\square \text { Possibility of an excessive information relay to } \\
\text { external parties }\end{array}$ \\
\hline
\end{tabular}

DATA OF PERSON IN CHARGE TO COMPLETE THE QUESTIONAIRE (For further contacts in case of doubt about the data presented)

\begin{tabular}{|c|c|}
\hline Department/Service_ & _Post__ \\
\hline Phone & \\
\hline E-mail__ & \\
\hline Signature & Date \\
\hline
\end{tabular}




\section{References}

[1] ISO (International Organisation for Standardization). International standard ISO 14031: environmental management: environmental performance evaluation: guidelines. Geneva, Switzerland: International organisation for standardization; 1999.

[2] Wathey D, O'Reilly M. ISO 14031: a practical guide to developing environmental performance indicators for your business. London, UK: The Stationery Office; 2000

[3] Bennett M, James P. ISO 14031 and the future of environmental performance evaluation. In: Bennett M, James P, Klinkers L, editors. Sustainable measures: evaluation and reporting of environmental and social performance. Sheffield, UK: Greenleaf Publishing; 1999. p. 76-97.

[4] Ilinitch AY, Soderstrom NS, Thomas TE. Measuring corporate environmental performance. Journal of Accounting and Public Policy 1998;17: 383-408.

[5] Epstein M]. Measuring corporate environmental performance: best practices for costing and managing an effective environmental strategy. Institute of Management Accountants, McGraw-Hill; 1996.

[6] Armstrong M, Baron A. Performance management: the new realities. London, UK: Chartered Institute of Personnel and Development; 1998.

[7] Ramos TB, Alves I, Subtil R, Melo JJ. Environmental pressures and impacts of public sector organizations: the case of the Portuguese military. Progress in Industrial Ecology - An International Journal 2007:4:363-81.

[8] Flynn N. Public sector management. Harlow, England: Pearson Education; 2002.

[9] Boland T, Fowler A. A systems perspective of performance management in public sector organisations. The International Journal of Public Sector Management 2000;13:417-46.

[10] Brignall S, Modell S. An institutional perspective on performance measurement and management in the "New Public Sector". Management Accounting Research 2000;11:281-306.

[11] Burritt RL, Welch S. Accountability for environmental performance of the Australian commonwealth public sector. Accounting, Auditing \& Accountability Journal 1997;10:532-61.

[12] Mohninger B. Approaches for water and energy conservation in the government of Jamaica [draft]. Ottawa, Canada; 2000

[13] Mohninger B. Approaches for green procurement in the government of Jamaica [draft]. Ottawa, Canada; 1999.

[14] Mohninger B. Approaches for solid waste management in the government of Jamaica [draft]. Ottawa, Canada; 1999.

[15] USDOE/USEPA (United States Department of Energy/United States Environmental Protection Agency). Environmental management systems primer for federal facilities, DOE/EH-0573. Washington, DC: Office of Environmental Policy \& Assistance, U.S. Department of Energy; Federal Facilities Enforcement Office, U.S. Environmental Protection Agency; 1998.

[16] USEPA (United States Environmental Protection Agency). Implementation guide for the code of environmental management principles for federal agencies (CEMP), EPA 315-B-97-001. Washington, DC: U.S. Environmental Protection Agency, Federal Facilities Enforcement Office; 1997.

[17] USEPA (United States Environmental Protection Agency). Generic protocol for conducting environmental audits of federal facilities: phase 3: auditing environmental management systems, EPA 300-B-96-012B. Prepared by the members of the interagency environmental audit protocol workgroup for the federal community. Washington, DC: U.S. Environmental Protection Agency, Office of Enforcement \& Compliance Assurance; 1996.

[18] US Government (United States Government). Government performance and results act of 1993. Washington, DC: US Government; 1993.

[19] UK MOD (United Kingdom Ministry of Defence). Framework for sustainable development on the government estate: ministry of defence sustainable development strategy. United Kingdom Ministry of Defence; 2003.

[20] DND/CF (Department of National Defence and the Canadian Forces). Environmentally sustainable defence activities: sustainable development strategy 2003. Canada: Department of National Defence and the Canadian Forces; 2003.

[21] Australian DoD (Australian Department of Defence). Environmental performance reporting framework (EPRF). Australian Department of Defence. Available from: http://www.defence.gov.au/environment/pages/eprf.htm; 2002 [accessed 22.04.04]

[22] DND/CF (Department of National Defence and the Canadian Forces). Enhanced performance measurement framework. Canada: Department of National Defence and the Canadian Forces; 2000.

[23] US DoD (United States Department of Defense). Environmental management system (EMS) implementation criteria and metrics. Washington, DC: Department of Defense; 2003.

[24] US DoD (United States Department of Defense). Revising pollution prevention \& compliance metrics. Washington, DC: Department of Defense; 2001.

[25] Netherlands MOD (The Netherlands Ministry of Defence). Environmental performance indicators. Netherlands: The Netherlands Ministry of Defence; 2000.

[26] US DoD (United States Department of Defense). Environmental performance indicators. Washington, DC: Department of Defense; 1999.

[27] US DoD (United States Department of Defense). Environmental performance indicators. Department of Defense: Washington, DC; (n.d.).
[28] Turner R, Greco P. EMS success story at naval air station in Willow Grove, Pennsylvania: how an EIMS supports effective EMS implementation. Federal Facilities Environmental Journal 2003 Summer:101-12.

[29] Wood JD, Baetz LL, Shaheen CA. Environmental management systems (EMS) implementation at chemical demilitarization facilities. Federal Facilities Environmental Journal 2003 Summer:77-86.

[30] Wark NJ, Verrier FJ. Australian defence organisation environmental management initiatives: shoalwater bay training area. Federal Facilities Environmental Journal 2002 Spring:53-63.

[31] Beal S. ISO 14001 and its role in environmental preservation. Federal Facilities Environmental Journal 2002 Autumn:107-13.

[32] Taylor C, Kivela K, Kontess W, Crum J. Environmental management systems and the air force environmental program. Available from: https://www.denix. osd.mil/denix/Public/Library/PRO97/ems.html [accessed 10.10.01].

[33] US DoD (United States Department of Defense). ISO 14001 environmental management systems pilot study: final report. Washington, DC: Department of Defense; 2000.

[34] USMC (United States Marine Corps). Short guide to environmental management systems (EMS). Headquarters United States Marine Corps, Installations and Logistics Department; 2000.

[35] Steucke PT. Public sector value of an ISO 14000 certified environmental management system: the Fort Lewis army installation in Washington state. Environmental Practice 2000;2:288-90.

[36] NATO (North Atlantic Treaty Organisation). Environmental management systems in the military sector: final report of the pilot study group, report no 240. North Atlantic Treaty Organisation, Committee on the Challenges of Modern Society; 2000

[37] Drawbaugh R. Use of environmental management systems and ISO 14001 in the public sector. US Department of Defense. In: Environmental management systems and ISO 14001: federal facilities council report No.138. Washington, DC: National Academy Press; 1999. p. 18-21.

[38] LFC/DND/CF (Land Force Command. Department of National Defence and the Canadian Forces). Environmental management system: land force command. Canada: Land Force Command. Department of National Defence and the Canadian Forces; 1999.

[39] Lederer SE. Use of an environmental management system at an operating military facility. In: Annual joint service pollution prevention conference. Air Force Center for Environmental Excellence; 1997.

[40] Ramos TB, Melo JJ. Environmental management practice in the defence sector: assessment of the Portuguese military's environmental profile. Journal of Cleaner Production 2005;13:1117-30.

[41] MDN (Ministério da Defesa Nacional). Anuário Estatístico da Defesa Nacional de 2001. Lisboa: Ministério da Defesa Nacional; 2002.

[42] MARN (Ministério do Ambiente e dos Recursos Naturais). Plano Nacional da Política de Ambiente. Lisboa: Ministério do Ambiente e dos Recursos Naturais; 1995.

[43] MDN (Ministério da Defesa Nacional). A Protecção Ambiental nas Forças Armadas. Lisboa: Ministério da Defesa Nacional; 2001.

[44] NATO (North Atlantic Treaty Organisation). STANAG 7141 EP [Edition 1] (Ratification Draft 1) - joint NATO doctrine for environmental protection during NATO led operations and exercises. Brussels: North Atlantic Treaty Organisation, NATO Standardization Agency, Joint Service Board; 2002.

[45] Wheater CP, Cook P. Using statistics to understand the environment. London, UK: Routledge; 2000.

[46] Gibbons JD. Nonparametric statistics: an introduction. Sage university paper series on quantitative applications in the social sciences, series no. 07-090. Newbury Park, CA: Sage Publications; 1993.

[47] Johnston A, Smith A. The characteristics and features of corporate environmental performance indicators: a case study of the water industry of England and Wales. Eco-Management and Auditing 2001;8:1-11.

[48] O'Reilly M, Wathey D, Gelber M. ISO 14031: effective mechanism to environmental performance evaluation. Corporate Environmental Strategy 2000;7:267-75.

[49] Jones K. Study on environmental reporting by companies. Centre for Environmental Informatics, University of Sunderland. European Commission; 1999.

[50] Ljungdahl F. The development of environmental reporting in Swedish listed companies: practice, concepts, causes. Lund, Sweden: Faculty of Social Sciences at Lund University; 1999.

[51] Kuhre WL. ISO 14031: environmental performance evaluation (EPE). New Jersey: Prentice Hall, Inc.; 1998.

[52] GEMI (Global Environmental Management Initiative). Measuring environmental performance: a primer and survey of metrics in use. Washington, DC: Global Environmental Management Initiative; 1998.

[53] Phillips L, Perry B. Assessment of potential environmental health risks of residue of high-explosive munitions on military test ranges: comparison in a humid and arid climate. Federal Facilities Environmental Journal 2002 Spring:7-25.

[54] Carter N, Klein R, Day P. How organizations measure success: the use of performance indicators in government. London: Routledge; 1992.

[55] Dias-Sardinha I, Reijnders L, Antunes P. From environmental performance evaluation to eco-efficiency and sustainability balanced scorecards: a study of organizations operating in Portugal. Environmental Quality Management 2002 Winter:61-4.

[56] PMSGO (The Committee on Performance Measurement for Sustainable Government Operations). Environmental performance measures for 
government operations: a guidance document [version 1.0]. Canada: Prepared by Marbek Resource Consultants for the Committee on Performance Measurement for Sustainable Government Operations (PMSGO); 1999.

[57] DND/CF (Department of National Defence and the Canadian Forces). Environmentally sustainable defence activities: a sustainable development strategy for national defence. Canada: Department of National Defence and the Canadian Forces; 2003.

[58] UNEP/RIVM (United Nations Environment Programme and National Institute of Public Health and the Environment). An overview of environmental indicators: state of the art and perspectives. UNEP/EATR.94-01; RIVM/ 402001001. Nairobi: United Nations Environment Programme; 1994. 